\title{
Insertion Mutation
}

National Cancer Institute

\section{Source}

National Cancer Institute. Insertion Mutation. NCI Thesaurus. Code C19295.

Any rearrangement to the genomic content that adds one or more extra nucleotides into the DNA. Insertions may be reversible, particulary if caused by transposable elements. They may alter the reading frame of a gene, or may cause large scale additions of genomic DNA. 